\title{
CARBON NANOMATERIALS APPLICATION AS A COUNTER ELECTRODE FOR DYE-SENSITIZED SOLAR CELLS
}

\begin{abstract}
The paper presents the results of the structure investigation of a counter electrode in dye-sensitized solar cells using the carbon nanomaterials. Solar cells were fabricated on the glass with transparent conductive oxide TCO (10 $/$ /sq). Nanocrystalline titania based photoanode was prepared by spreading $\mathrm{TiO}_{2}$ paste onto $\mathrm{TCO}$ glass and subsequently annealed at $450^{\circ} \mathrm{C}$ for at least $30 \mathrm{~min}$ to convert anatase phase and make an interparticle network. After then the nanostructured titania films was immersed into an ethanolic solution of the ruthenium-based dye. As a counter electrodes of dye-sensitized solar cells composite films of carbon nanomaterials and polystyrene sulfonate doped poly (3,4-ethylenedioxythiophene) PEDOT-PSS (Sigma-Aldrich) were deposited onto TCO substrates. Because carbon nanoelements and titanium oxide consist of nano-metric structural units to determine the properties of the cells and their parameters several surface sensitive techniques and methods, i.e. Raman spectroscopy, Scanning Electron Microscopy (SEM), High-Resolution Transmission Electron Microscopy (HRTEM), and electric properties of conductive layers were used.
\end{abstract}

Keywords: dye-sensitized solar cell; carbon nanomaterials; counter electrode; nanocrystalline photovoltaic cells

\section{Introduction}

It is generally believed that fossil fuels, which cause degradation of environment due to pollution, will be replaced by renewable energy sources. A great interest has solar energy with its unlimited quantity, which are the cleanest and most abundant renewable energy sources available. This energy is in the form of solar radiation and makes the production of solar electricity possible [1-4].

Dye-sensitized solar cells DSSC (also known as Grätzel cell) are a third generation photovoltaic cells that convert a visible light into electrical energy. DSSC can be used to produce electricity in a wide range of light conditions, indoors and outdoors, enabling the user to convert light into energy to power a broad range of electronic devices. This kind of solar cells are a lowcost, and they belong to the group of thin film solar cells $[1,5,6]$.

In the case of the original Grätzel design, dye-sensitized solar cells have three primary parts: photoanode, counter electrode $\mathrm{CE}$ and electrolyte solution commonly with dissolved iodide/ triiodide redox couple $[6,7]$.

Photoanode is a nanocrystalline film formed by a wide bandgap semiconductor deposited on a glass substrate covered with the Transparent Conductive Oxide TCO layer and then immersed in a dye. The TCO layer allows sunlight penetrating into dye-sensitized solar cell while conducting electron carriers to outer circuit $[8,9]$. Most commonly used semiconductor is titanium oxide because of its the good structural stability, light sensitivity, non-toxicity and low price. The photoanode in DSSC plays roles of loading dyes, accepting and transporting electrons [6].

The counter electrode is one of the key elements of the dyesensitized solar cells, which acts as a catalyst for the reduction reaction and the redox couple and is used as the mediator to dye regenerate after electron injection. For high-performance counter electrode has to show high catalytic activity towards the reduction reaction and electrical conductivity [10].

Choosing the suitable material and a good understanding of various processing methods to form products with required properties are fundamental factors to decide the right manufacturing methods [11-16]. The counter electrode is prepared by depositing a thin layer of platinum catalyst on a TCO glass substrate, but it is also one of the factors that significantly increase productions costs. Due to the shortage of noble platinum and its corrosion in the electrolyte, alternative materials with low cost such as carbon [10,17-19] and conductive polymers have been developed.

Nanocrystalline photovoltaic cells constitute an attractive and modern development trend in photovoltaic, especially when using carbon nanoelements in their structure. Recently, much importance is attributed to the counter electrode based on carbon because of the high electrical conductivity, corrosion resistance to iodide, high reactivity for the reduction of triiodide and low cost. To date, lots of carbon materials have been reported to be potentially used as a counter electrode: carbon nanotubes [20-

\footnotetext{
SILESIAN UNIVERSITY OF TECHNOLOGY, INSTITUTE OF ENGINEERING MATERIALS AND BIOMATERIALS, KONARSKIEGO ST. 18A, 44-100 GLIWICE, POLAND

Corresponding author: aleksandra.drygala@polsl.pl
} 
22], activated carbon [23], soot [24], graphite [25], graphene [26-31], mixtures of the above [32].

While graphite has a low catalytic activity towards the reduction of triiodide ion, its large surface area analogical as in soot and carbon nanotubes makes that in some cases dye-sensitized solar cells with this type of CEs are achieving even better performance than with platinum counter electrode. However, most of the carbon materials must have a thickness of several microns making them opaque $[30,33,34]$.

Carbon nanotubes are almost transparent, flexible and strong, what make them the ideal material for transparent counter electrodes for dye-sensitized solar cells. Graphene has attracted great interest due to its excellent mechanical, electrical, thermal and optical properties. Graphene is a two-dimensional (2D) crystal that has unique electronic property and strong catalytic activity. On the other hand, graphene oxide GO obtained by chemical oxidation method and later reduced chemically or thermally has excellent electrocatalytic activity due to defects produced during oxidation of graphene sheets [35-37].

Herein, in this study, we demonstrate a facile, fast and cost-efficiency way to fabricate efficient DSSCs containing carbon nanotubes/PEDOT:PSS and graphene/PEDOT:PSS counter electrodes. The graphene-based CEs were produced by depositing both $\mathrm{GO}$ and thermally reduced graphene oxide $\mathrm{rGO}$ over a FTO-coated glass substrate. Because carbon nanoelements and titanium oxide consist of nano-metric structural units to determine the properties of the cells and their parameters modern research methods, first of all, Raman spectroscopy, HRTEM, SEM, and XRD were used. It is expected that electrical properties of the DSSC with carbon nanomaterials CE can be improved. This work compares and describes the microstructure and electrical properties of a dye-sensitized solar cell consisting of carbon materials and graphene-based counter electrodes. Further optimization of the fabrication procedure is under study.

\section{Experimental details}

Poly(3,4-ethylenedioxythiophene) polystyrene sulfonate PEDOT:PSS was purchased from Sigma-Aldrich. Ruthenium dye N3 - Cis-diisothiocyanato-bis (2,2'-bipyridyl-4,4'-dicarboxylic acid) ruthenium (II), iodolyte, highly dispersed titania nanoparticle paste for the deposition of transparent active mesoporous films were purchased from Solaronix (Switzerland). Platinum paste was purchased from 3D Nano (Poland).

The FTO (fluorine-doped tin oxide) glass substrates $(10 \Omega / \square$, Solaronix) were cut into pieces with a size of $2,5 \times 2,5 \mathrm{~cm}^{2}$ and ultrasonically cleaned in distilled water, acetone and ethanol for $10 \mathrm{~min}$, respectively.

Multiwalled carbon nanotubes MWCNTs were produced by CVD method and few layer graphene oxide FLGO were purchased from Cheap Tubes (USA).

The production steps of dye-sensitized solar cells were shown in Figure 1. As counter electrodes were used carbon nanomaterials and platinum. Dye-sensitized solar cells have the following arrangement of layers (Fig. 2):

- $\quad \mathrm{FTO}$ glass $/ \mathrm{TiO}_{2} /$ dye/electrolyte/platinum/FTO glass,

- FTO glass/TiO2/dye/electrolyte/graphene/FTO glass,

- $\quad$ FTO glass $/ \mathrm{TiO}_{2} /$ dye/electrolyte/nanotube/FTO glass.

where: FTO glass is glass with a layer of fluorine doped tin oxide FTO.

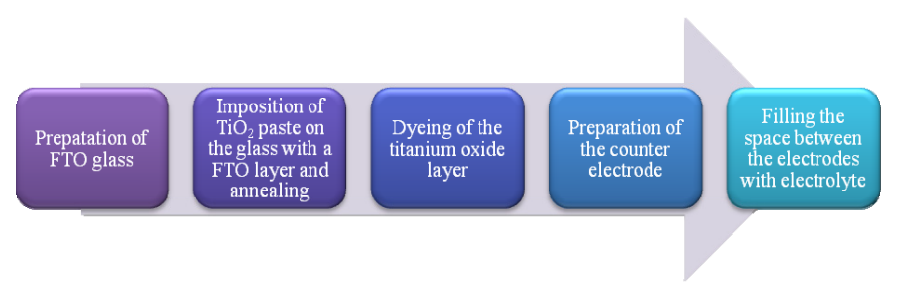

Fig. 1. Production steps of dye-sensitized solar cell

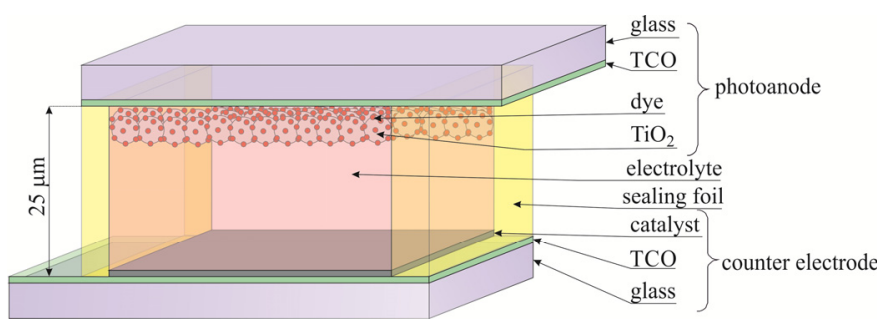

Fig. 2. Construction of dye-sensitized solar cell

PEDOT:PSS solution $\left(0,8 \%\right.$ in $\left.\mathrm{H}_{2} \mathrm{O}\right)$ was mixed with multiwalled carbon nanotubes $(0,01 \mathrm{~g})$ dispersion in ethanol at a given volume ratio and sonicated for $15 \mathrm{~min}$ to form a stable mixture. The mixture was then spin coated on clean FTO substrates at $6000 \mathrm{rpm}$ for $30 \mathrm{~s}$, and the resulted film was dried at room temperature under vacuum. In order to reduce graphene oxide, thermal annealing reduction was used. Graphene oxide was heated at $500^{\circ} \mathrm{C}$ for $30 \mathrm{~min}$ under protection of $\mathrm{Ar} / \mathrm{H}_{2}$ flow. Then the reduced graphene oxide and graphene oxide were mixed with PEDOT:PSS (to prevent reaggregation) and deposited on two separately FTO substrates by spin coating method and then dried at room temperature under vacuum.

Titanium paste was screen-printed on FTO substrates, followed by being sintered at $500^{\circ} \mathrm{C}$ for $30 \mathrm{~min}$. After cooling down to $80^{\circ} \mathrm{C}$, the sintered photoanodes were immersed in an anhydrous ethanol solution of 0,5 mM. N3 dye for $24 \mathrm{~h}$ at without access to light. Once removed, the electrode was washed with ethanol to remove excess dye and allowed to dry. The CE based on platinum was prepared by depositing a Pt paste onto the entire surface of conductive glass using a screen-printing method, followed by heat treatment at $500^{\circ} \mathrm{C}$ for $30 \mathrm{~min}$. The internal space between photoanode and counter electrode was controlled to be $25 \mu \mathrm{m}$ by Surlyn foil (Solaronix). The photoanode and counter electrode were sealed with $25 \mu \mathrm{m}$ thick Surlyn frame at $100^{\circ} \mathrm{C}$ for $15 \mathrm{~s}$. After sealing the cells were filled with the electrolyte solution with redox couple $I^{-} / I_{3}^{-}$.

Scanning Electron Microscopic (SEM) images were taken with a Zeiss Supra 35. Graphene and carbon nanotubes microstructure were tested with the use of the TITAN 80-300 ultrahigh 
resolution scanning/transmission electron microscope. X-ray Diffraction (XRD) analysis was recorded on a Panalytical X'Pert Pro diffractometer with $\mathrm{Cu} \mathrm{K} \alpha$ radiation. The transmittance of carbon nanomaterials was measured by Thermo Scientific Evolution 220 spectrophotometer. Current-voltage characteristics of dye-sensitized solar cells with carbon nanotubes and platinum counter electrodes were performed at Standard Test Conditions (irradiance intensity $1000 \mathrm{~W} / \mathrm{m}^{2}$, temperature $25^{\circ} \mathrm{C}$, spectrum AM1.5) using PV Test Solutions Tadeusz Żdanowicz Solar Cell I-V Tracer System with solar simulator and Keithley 2400 source meter. The intensity of incident light was calibrated by National Renewable Energy Laboratory NREL-certified silicon reference cell equipped with KG5 filter.

\section{Results and discussion}

In order to prepare dye-sensitized solar cells with platinum, carbon nanotube, and graphene-based counter electrode there were also prepared photoanodes by screen printing method. Fig. 3 shows the SEM images of a cross-section FTO glass coated with titanium dioxide after sintering at $500^{\circ} \mathrm{C}$. Uniform and smooth titanium dioxide thin film was obtained. Fig. 4 shows the X-ray diffraction pattern of titanium dioxide where $\mathrm{A}$ is nanocrystalline anatase - one of mineral forms of titanium dioxide and $\mathrm{SnO}_{2}$ is glass substrate coated with FTO.

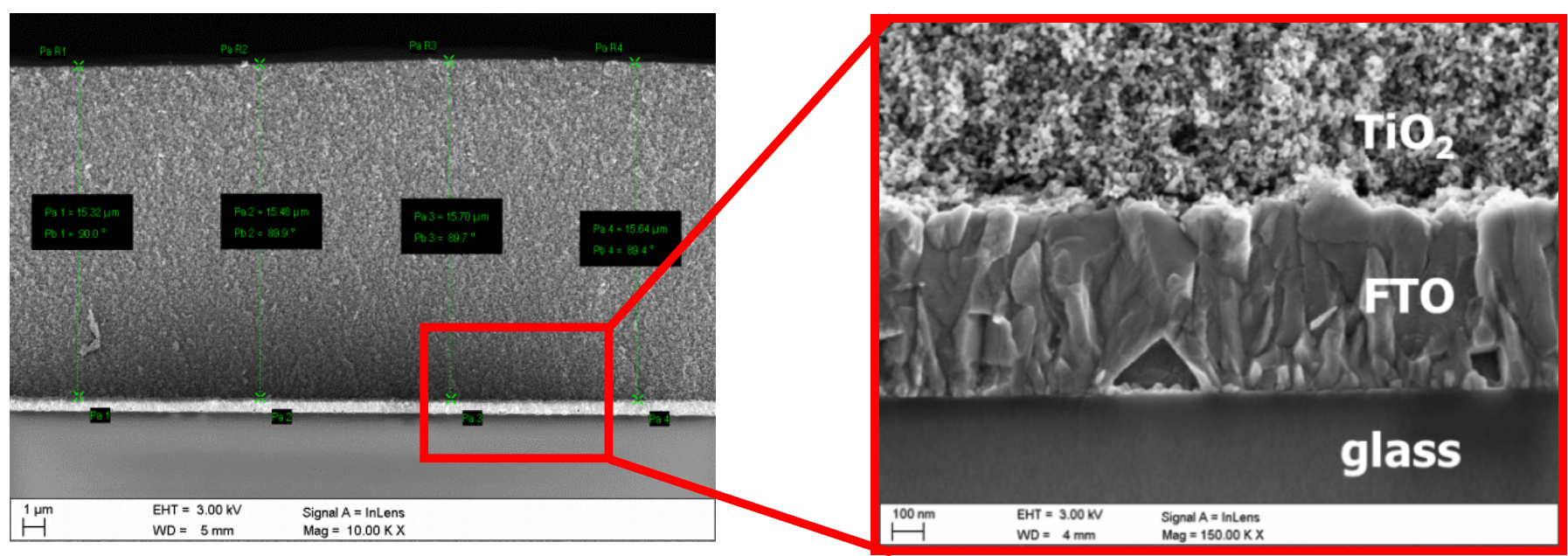

Fig. 3. Cross-section of FTO glass coated with titanium dioxide after sintering, SEM

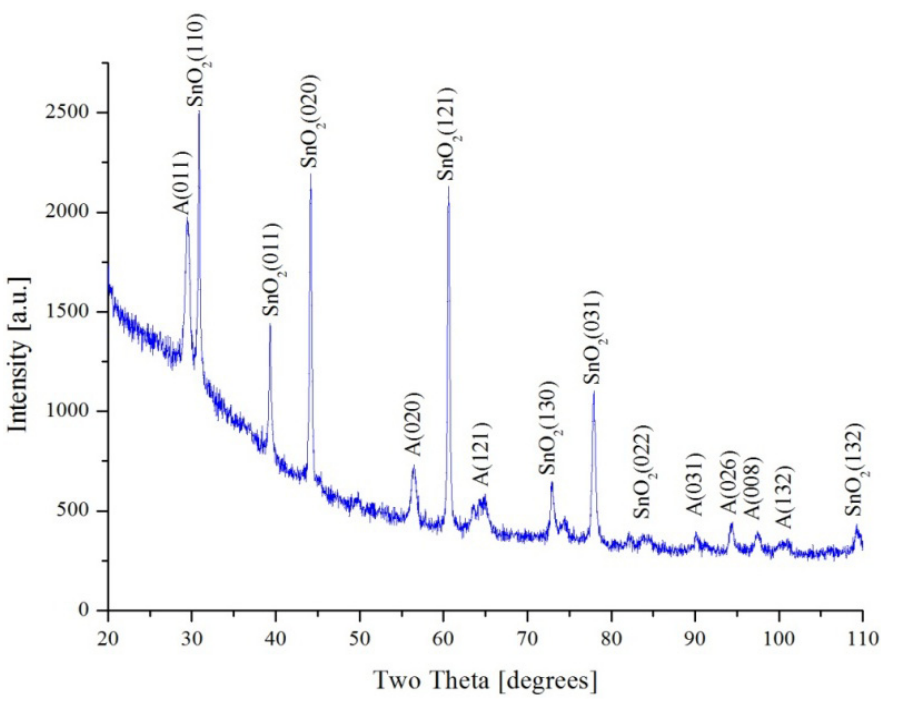

Fig. 4. X-ray diffraction pattern of photoanode

Figures $5 \mathrm{a}$ and $5 \mathrm{~b}$ show the microstructure of carbon nanotubes and graphene-based counter electrodes respectively. We can observe that severely agglomerated CNTs and highly conductive PEDOT:PSS has the uniform structure and little pores generated in the structure. By adding carbon nanotube to the counter electrode, it is possible to obtain large surface area, therefore larger contact surface. Well dispersed, uniform and smooth graphene thin films were obtained with PEDOT:PSS. The thickness of carbon nanotubes and graphene-based films was about $10 \mu \mathrm{m}$.

Figure 6a shows the TEM image of multiwall carbon nanotubes used as an electrode in DSSC; results confirm the high purity of analysed materials. We can see in the TEM image small content of amorphous carbon deposits. The TEM investigations are shown on Figure $6 \mathrm{~b}$ and the obtained data exhibit that $\mathrm{rGO}$ sheets consist of few layers $(n<6)$ stacked each other.

The nature of the graphene-based counter electrode has been confirmed by the Raman scattering spectroscopy. Figure 7a shows the Raman spectra of carbon nanotubes thin film CE. The intensity of the D module relative to the module $\mathrm{G}$ suggests a defect structure of the tested material. Figure $7 \mathrm{~b}$ shows the Raman spectra of graphene thin film substrates that were obtained using an excitation laser of $512 \mathrm{~nm}$. All graphene samples record two major Raman peak at $\sim 1339$ and $\sim 1596 \mathrm{~cm}^{-1}$ corresponding to $\mathrm{D}$ and $\mathrm{G}$ bands. The increased intensity ratio $\mathrm{I}_{\mathrm{D}} / \mathrm{I}_{\mathrm{G}}$, which defines the quantitative disorder in graphene, is a consequence of a high number of defects in materials resulting from the heat treatment after oxidation and reduction process (Table 1). 
30

a)

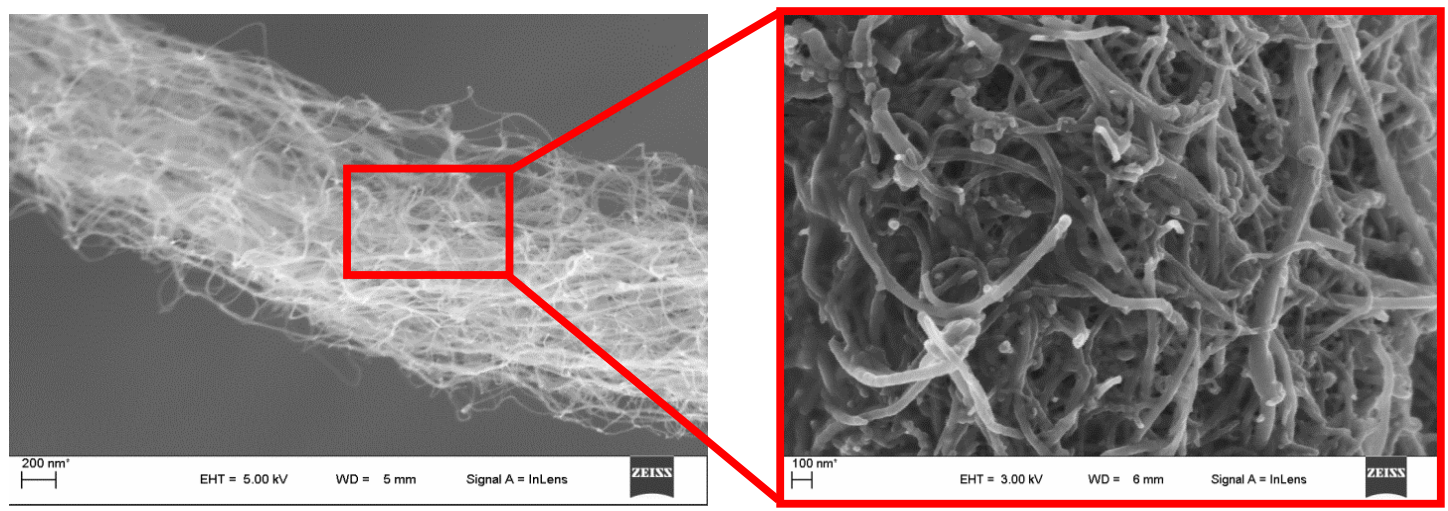

b)

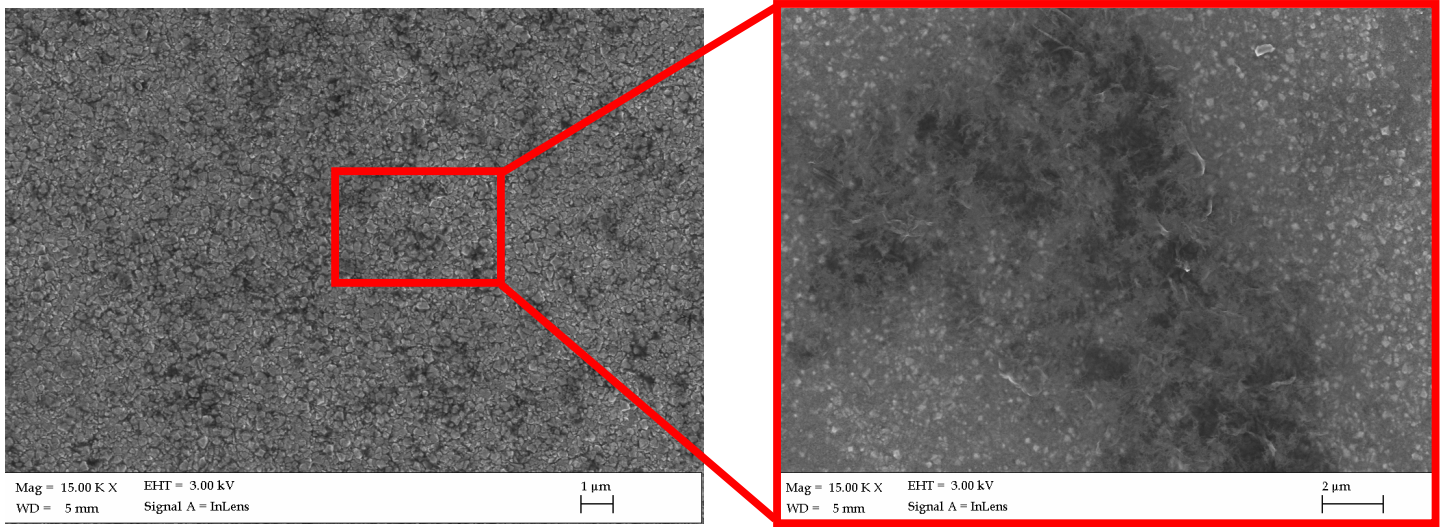

Fig. 5. The microstructure of the layers of conductive polymer PEDOT:PSS with: a) MWCNTs, b) rGO, SEM

a)

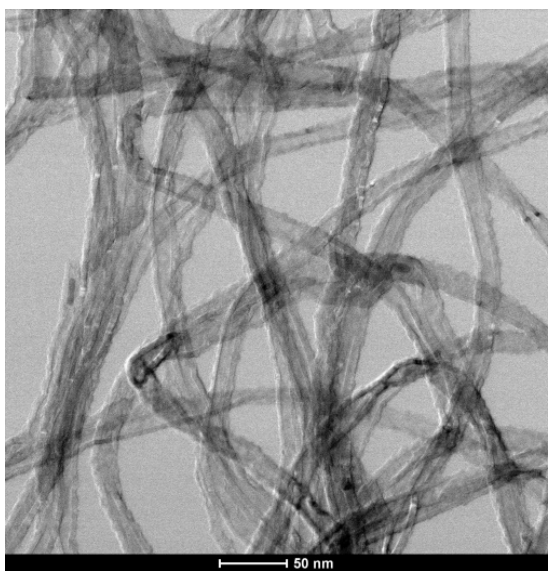

b)

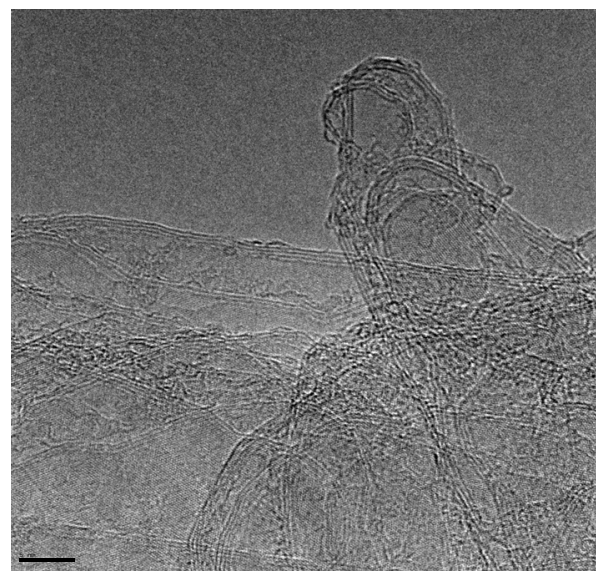

Fig. 6. Morphology of: a) carbon nanotubes, b) reduced graphene oxide, TEM
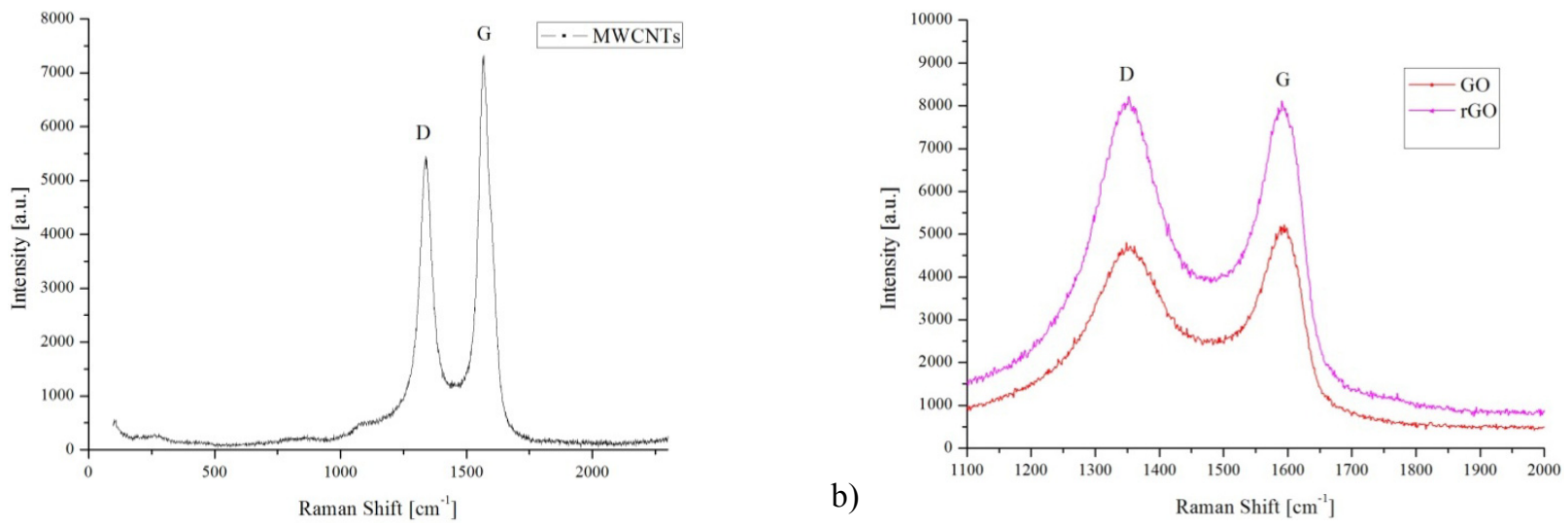

Fig. 7. Raman spectra of: a) carbon nanotubes, b) graphene thin films 
TABLE 1

$I_{D} / I_{G}$ ratio of carbon materials used as a counter electrode in DSSCs

\begin{tabular}{|c|c|}
\hline \hline Material & $\boldsymbol{I}_{\boldsymbol{D}} / \boldsymbol{I}_{\boldsymbol{G}}$ ratio \\
\hline GO & 0,8935 \\
\hline rGO & 1,0423 \\
\hline MWCNTs & 0,8521 \\
\hline
\end{tabular}

Optical properties of carbon nanomaterials layer deposited on FTO glass were characterized by transmittance over the wavelength range from $200 \mathrm{~nm}$ to $1000 \mathrm{~nm}$. In Fig. 8 transmittance of carbon nanomaterials layer is shown. The transmittance of graphene oxide and reduced graphene oxide films coated FTO glass are higher than $60 \%$ in the wavelength range $430-780 \mathrm{~nm}$. Multiwalled carbon nanotubes have a transmittance higher than $50 \%$ in the wavelength range $350-1000 \mathrm{~nm}$. It is shown that transmittance of all samples increases gradually through a visible region. The largest transmittance has substrate without carbon nanomaterials layer.

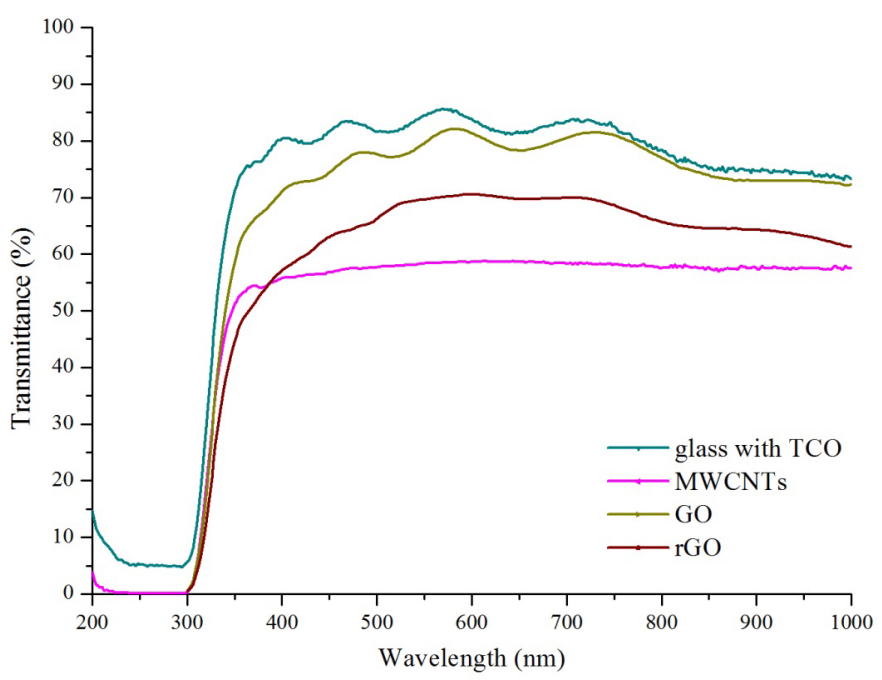

Fig. 8. Transmittance of carbon nanomaterials deposited on glass with TCO layer

Table 2 shows the electrical parameters by means of a voltage of three dye-sensitized solar cells with three different counter electrodes. The open-circuit voltage $\left(V_{o c}\right)$, short-circuit photocurrent density $\left(J_{s c}\right)$ and efficiency $(\eta)$ of the cells are listed in Table 2. The measurements were carried out under illumination of artificial light (irradiance intensity $1000 \mathrm{~W} / \mathrm{m}^{2}$, spectrum AM1.5). Energy conversion efficiency of DSSCs using the reduced graphene oxide/PEDOT:PSS composite film contained $1 \%$ wt graphene oxide as a counter electrode was measured to be $6,62 \%$, and $J_{s c}$ and $V_{o c}$ were close to those of DSSC with $\mathrm{Pt}$ counter electrode. The relatively low electric properties of dyesensitized solar cells with GO counter electrode might be possible due to lower series resistance and catalytic activity of the CEs. The PV performance improved after heat treatment of graphene oxide. The investigated effect of carbon materials electrodes on the efficiency of DSSC showed that the best efficiency has reduced graphene oxide what can be caused by higher catalytic activity and increasing the surface area of the counter electrode in comparison to carbon nanotubes.

TABLE 2

Photovoltaic performance data of DSSCs fabricated by the counter electrode of graphene oxide, reduced graphene oxide, carbon nanotubes and platinum

\begin{tabular}{|c|c|c|c|}
\hline \hline Type of counter electrode & $\boldsymbol{V}_{\boldsymbol{o c}} \mathbf{( V )}$ & $\boldsymbol{J}_{\boldsymbol{s c}}\left(\mathbf{m A} / \mathbf{c m}^{\mathbf{2}}\right)$ & $\boldsymbol{\eta} \mathbf{( \% )}$ \\
\hline GO/PEDOT:PSS & 0,51 & 9,4 & 1,50 \\
\hline rGO/PEDOT:PSS & 0,68 & 11,10 & 6,62 \\
\hline MWCNT/PEDOT:PSS & 0,65 & 11,02 & 5,97 \\
\hline $\mathrm{Pt}$ & 0,70 & 12,90 & 7,16 \\
\hline
\end{tabular}

\section{Conclusions}

In conclusion, we demonstrated the application of carbon nanomaterials as counter electrodes for DSSCs to solve problems of high costs of platinum CEs. As a counter electrode were used three carbon materials: graphene oxide, reduced graphene oxide and multiwalled carbon nanotubes. Graphene-based films were prepared from reduced graphene oxide and graphene oxide mixed with PEDOT:PSS on FTO glass sheets. To reducing graphene oxide thermal annealing in $500^{\circ} \mathrm{C}$ for $30 \mathrm{~min}$ was used. Carbon nanotubes counter electrodes were prepared by mixing with PEDOT:PSS, followed by spin coating method. Conventional counter-electrodes of platinum was also prepared and used as a reference. It has been found that counter electrode with graphene-based materials shows higher transmittance compared to multiwalled carbon nanotubes layer.

As a result, the DSSC with the counter electrode of $\mathrm{rGO}$ / PEDOT:PSS showed a high energy conversion efficiency of $6,62 \%$ under irradiance intensity $1000 \mathrm{~W} / \mathrm{m}^{2}$, spectrum AM1.5. Although these results are relatively low in comparison to conventional platinum CEs, the composite of PEDOT:PSS with reduced graphene oxide as well as with carbon nanotubes or graphene oxide can be fabricated at room temperature, which makes them applicable to polymer substrates.

\section{Acknowledgment}

The project was funded by the National Science Centre on the basis of the contract No.DEC-2013/09/B/ST8/02943.

\section{REFERENCES}

[1] A. Hagfeldt, M. Grätzel, Accounts Chem. Res. 33, 5, 269-277 (2000).

[2] L.A. Dobrzański, T. Tański, A. Dobrzańska-Danikiewicz, E. Jonda, M. Bonek, A. Drygała, Structures, properties and development trends of laser-surface-treated hot-work steels, light metal alloys and polycrystalline silicon, in J. Lawrence, D.G. Waugh (Ed.), 
Laser surface engineering: Processes and applications, Woodhead Publishing Series in Electronic and Optical Materials (2015).

[3] L.A. Dobrzański, M. Musztyfaga, A. Drygała, Stroj. Vestn. J. Mech. E. 59, 3, 175-182 (2013).

[4] L.A. Dobrzański, A. Drygała, Mater. Sci. Forum 706-709, 829-834 (2012).

[5] A. Kay, M. Grätzel, Sol. Energ. Mat. Sol. C. 44, 99-117 (1996).

[6] B. O’Regan, M. Grätzel, Nature 353, 737-740 (1991).

[7] F. Miao, B. Tao, P.K. Chu, Electrochim. Acta 96, 61-65 (2013).

[8] J. Domaradzki, D. Kaczmarek, K. Drabczyk, P. Panek, Mater Sci-Poland. 33, (2), 363-368 (2015)

[9] K. Drabczyk, J. Domaradzki, P. Panek, D. Kaczmarek, Microelectron Int. 32, 3, 149-151 (2015).

[10] S. Xu, Y. Luo, W. Zhong, Sol. Energy 85, 2826-2832 (2011).

[11] K. Drabczyk, P. Panek, Circuit World 40, 1, 23-26 (2014).

[12] D. Szewieczek, S. Lesz, J. Mater. Process. Tech. 162, 254-259 (2005).

[13] G. Kulesza, P. Panek, P. Zieba, Arch. Civ. Mech. Eng. 14, 4, 595-601 (2014)

[14] K. Lukaszkowicz, L.A. Dobrzański, G. Kokot, P. Ostachowski, Vacuum 86, 2082-2088 (2012).

[15] A. Drygała, L.A. Dobrzański, M. Szindler, M.M. Szindler, M.Prokopiuk vel Prokopowicz, E. Jonda, Int. J. Hydrogen Energ 41, 18, 7563-7567 (2016)

[16] S. Lesz, R. Szewczyk, D. Szewieczek, A. Bieńkowski, J. Mater. Process. Tech. 157, 743-748 (2004).

[17] K. Li, Y. Luo, Z. Yu, M. Deng, D. Li, Q. Meng, Electrochem. Commun. 11, 1346-1349 (2009).

[18] Z. Huang, X. Liu, K. Li, D. Li, Y. Luo, H. Li, W. Song, L. Chen, Q. Meng, Electrochem. Commun. 9, 4, 596-598 (2007).

[19] K. Imoto, K. Takahashi, T. Yamaguchi, T. Komura, J. Nakamura, K. Murata, Sol. Energ. Mat. Sol. C. 79, 459-469 (2003).

[20] S.U. Lee, W.S. Choi, B. Hong, Sol. Energ. Mat. Sol. C. 94, 680-685 (2010).

[21] S. Peng, Y. Wu, P. Zhi, V. Thavasi, S.G. Mhaisalkar, S. Ramakrishna, J. Photoch. Photobio. A 223, 97-102 (2011).
[22] H. Anwar, A.E. George, I.G. Hill, Sol. Energy 88, 129-136 (2013).

[23] I.YY. Bu, J. Zheng, Mat. Sci. Semicon. Proc. 39, 223-228 (2015).

[24] H.K. Jun, M.A. Careem, A.K. Arof, Nanoscale Res. Lett. 9, 69 (2014).

[25] S. Shalini, R. Balasundara prabhu, S. Prasanna, Tapas K. Mallick, S. Senthilarasu, Renew. Sust. Energ. Rev. 51, 1306-1325 (2015).

[26] R. Cruz, D.A. Pcheco Tanaka, A. Mendes, Sol. Energy 86, 716-724 (2012).

[27] H. Wang, K. Sun, F. Tao, D.J. Stacchiola, Y.H. Hu, Angew. Chem. Int. Edit. 52, 35, 9210-9214 (2013).

[28] C.T. Hsieh, B.H. Yang, Y.F. Chen, Diam. Relat. Mater. 27-28, 68-75 (2012)

[29] D.W. Zhang, X.D. Li, H.B. Li, S. Chen, Z. Sun, X.J. Yin, S.M. Huang, Carbon 49, 5382-5388 (2011).

[30] H.S. Jang, J.M. Yun, D.Y Kim, D.W. Park, S.I. Na, S.S. Kim, Electrochim. Acta 81, 301-307 (2012).

[31] Z.Y. Li, M.S. Akhtar, J.H Kuk, B.S. Kong, O.B. Yang, Mater. Lett. 86, 96-99 (2012).

[32] H. Choi, H. Kim, S. Hwang, W. Choi, M. Jeon, Sol. Energ. Mat. Sol. C. 95, 323-325 (2011)

[33] T.N. Murakami, S. Ito, Q. Wang, M.K. Nazeeruddin, T. Bessho, I. Cesar, P. Liska, R. Humphry-Baker, P. Comte, P. Pechy, M. Grätzel, J. Electrochem. Soc. 153, A2255-A2261 (2006).

[34] A.D. Dobrzanska-Danikiewicz, D. Cichocki, M. Pawlyta, D. Łukowiec, W. Wolany, Phys. Status Solidi B 251, 12, 2420-2425 (2014).

[35] W. Hong, Y. Xu, G. Lu, C. Li, G. Shi, Electrochem. Commun. 10, 1555-1558 (2008).

[36] N.T. Murakami, M. Grätzel, Inorg. Chim. Acta 361, 3, 572-580 (2008).

[37] K. Lukaszkowicz, M. Pawlyta, I. Pasternak, L.A. Dobrzański, M. Prokopiuk vel Prokopowicz, M. Szindler, A. Drygała, J. Sitek, Surf. Eng. 32, 11, 816-822 (2016). 